TABLE I-Leukaemia Patients

\begin{tabular}{|c|c|c|c|c|c|c|c|c|c|}
\hline \multirow{3}{*}{$\begin{array}{l}\text { Ages } \\
\text { (Years) }\end{array}$} & & \multicolumn{8}{|c|}{ Infections or Allergies } \\
\hline & & \multicolumn{2}{|c|}{ None } & \multicolumn{2}{|c|}{ Viral } & \multicolumn{2}{|c|}{ Bacterial } & \multicolumn{2}{|c|}{ Allergies } \\
\hline & & $\bar{I}-$ & $\mathbf{I +}$ & I- & $I+$ & I - & $I+$ & I - & It \\
\hline $\begin{array}{c}1-4 \\
5-9 \\
10-14\end{array}$ & . & $\begin{array}{r}47 \\
14 \\
8\end{array}$ & $\begin{array}{r}33 \\
4 \\
1\end{array}$ & $\begin{array}{l}32 \\
23 \\
20\end{array}$ & $\begin{array}{r}15 \\
8 \\
2\end{array}$ & $\begin{array}{l}16 \\
10 \\
10\end{array}$ & $\begin{array}{r}12 \\
3 \\
3\end{array}$ & $\begin{array}{r}10 \\
8 \\
5\end{array}$ & 4 \\
\hline Total & & 69 & 38 & 75 & 25 & 36 & 18 & 23 & 11 \\
\hline
\end{tabular}

$\mathrm{I}+$ indicates irradiated ín utero.

I - indicates not irradiated in utero.

TABLE II-Controls

\begin{tabular}{|c|c|c|c|c|c|c|c|c|c|}
\hline \multirow{3}{*}{\multicolumn{2}{|c|}{$\begin{array}{l}\text { Ages } \\
\text { (Y Years) }\end{array}$}} & \multicolumn{8}{|c|}{ Infections or Allergies } \\
\hline & & \multicolumn{2}{|c|}{ None } & \multicolumn{2}{|c|}{ Viral } & \multicolumn{2}{|c|}{ Bacterial } & \multicolumn{2}{|c|}{ Allergies } \\
\hline & & $I-$ & It & $I-$ & $I+$ & I- & $I+$ & $I-$ & $I+$ \\
\hline $\begin{array}{c}1-4 \\
5-9 \\
10-14\end{array}$ & $\begin{array}{l}\cdots \\
\cdots\end{array}$ & $\begin{array}{r}108 \\
78 \\
57\end{array}$ & $\begin{array}{r}50 \\
18 \\
9\end{array}$ & $\begin{array}{r}43 \\
108 \\
136\end{array}$ & $\begin{array}{l}12 \\
35 \\
20\end{array}$ & $\begin{array}{l}14 \\
25 \\
45\end{array}$ & $\begin{array}{r}3 \\
10 \\
5\end{array}$ & $\begin{array}{r}6 \\
10 \\
15\end{array}$ & $\begin{array}{l}0 \\
4 \\
2\end{array}$ \\
\hline Total & & 243 & 77 & 287 & 67 & 84 & 18 & 31 & 6 \\
\hline
\end{tabular}

$I+$ indicates irradiated in utero.

I Indicates irradiated in utero.
$\mathrm{I}$ - indicates not irradiated in utero.

in those not reporting viral diseases (or bacterial diseases or allergies) is given by $\mathbf{R}_{\mathbf{2}}=$ $(33 \times 108) /(47 \times 50)=1.52$. Our hypothesis states that these two relative risks should, except for random variation, be equal, that is $R_{1} / R_{2}=1$. The observed value of the ratio is 1.11 and we have calculated the one-sided exact probability (assuming all margins fixed in the $2 \times 2 \times 2$ table $^{2}$ ) of observing by chance a ratio as great or greater than this if the true ratio is unity. In no age group and in no infection or allergy grouping does the calculated probability level approach conventional levels of statistical significance. Again, when the findings in the three age groupings are combined, using a modification for $2 \times 2 \times 2$ tables of the Mantel and Haenszel ${ }^{3}$ method, none of the resulting $\chi^{2}$ values approaches statistical significance.

Of course, a statistical non-significant difference does not mean that a difference is not present. There are insufficient data available to reject a ratio of relative risks considerably in excess of unity (see, for example, the allergy group in table III). However, we would conclude that the data are certainly compatible with the hypothesis that children with leukaemia are simply more prone to infections and allergies before clinical onset of the disease-these characterize the disease itself and do not relate to the child's inherent susceptibility to leukaemia.

Hollocher ${ }^{4}$ reached a similar conclusion, using the data given in Bross and Natarajan's paper, that none of the groups were specially susceptible to radiation.

There are considerable problems associated with using post hoc markers as "indicators of susceptibility." The method of analysis we have used would be inappropriate if the "indicators" could not be considered as merely a possible result of the disease process. It should be noted, for example, that the finding of similar relative risks in those reporting infections and allergies and in those not reporting these conditions does not exclude the possibility that the conditions are indicators of a group particularly susceptible to radiation. So that if virus diseases are an indicator of a susceptible group to leukaemia induction by agents other than intrauterine irradiation the the relative risk of irradiation will be less in this group unless their susceptibility to radiation is also increased. (Rothman and $\mathrm{Keller}^{5}$ have discussed this problem in relation to the joint effects of alcohol and tobacco on the risk of cancer of the mouth and pharynx.) Had we found the relative risks to be markedly different, then an alternative hypothesis to that of Bross and Natarajan would be that children with radiation leukaemia simply differ in their susceptibility to infections and allergies compared with children who develop leukaemia but who were not irradiated (that is, radiation leukaemia is a different disease).

If one wishes to specify susceptible subgroups, a way must be found of identifying susceptible parents or fetuses before the intrauterine radiation is administered.

We are grateful to Professor B. MacMahon and Dr. K. Rothman for helpful discussions on this problem.

Department of Health and Social Security, University of Oxford

St. Catherine's College,

L. D. Hamilton

Bross, I. D. J., and Natarajan, N., New England Fournal of Medicine, 1972, 287, 107.

2 Zelen, M., Biometrika, 1971, 58, 129. National Cancer Institute, 1959, 22, 719.

Hollocher, T. C., New
Medicine, 1972, 287, 887 .

Rothman, K., and Keller, A., fournal of Chronic Diseases, 1972, 25, 711.

\section{Redesign of Medical Records in General Practice}

SIR,-Many doctors must have read the Department of Health's circular (ECN 946, April 1973) on the above subject with surprise and shock. We learn that the Department has adopted a recommendation that A4 international paper size requiring folders measuring $12 \frac{1}{4}$ in $\times 9 \frac{1}{2}$ in $(310 \mathrm{~mm} \times 240 \mathrm{~mm})$ should be adopted for general practice record sheets. It is admitted that the storage space required for these documents would be at least twice that needed for the present ECs 5 and 6. Suggestions are made for "small mobile steps" and other devices for use by one's staff in filing these large records.
It is to be officially recommended that extra space for secretarial work will now be required in practice premises, including health centres. The total cost of providing the new folders and medical records and in effecting the changeover, the new filing systems needed to accommodate them, and the alterations to buildings needed to accommodate the systems must run into tens of millions of pounds. Surely no Government should allow such expenditure.

I hope that the hitherto silent majority of family doctors who are quite content with the present conveniently small and portable record folders will unite in protest against this expensive new scheme. Imagine the inconvenience of having 30 or 40 of these large folders out on one's desk for a surgery, of having piles of them all over the office being got out for the next surgery, waiting to be filed, or for various administrative purposes. Imagine the large parcels to be posted to and from the executive council (or its successor) each week. Imagine having to carry 20 or 30 folders in one's car for patients being visited at home.

If those who are dissatisfied with the present medical record envelopes would take the trouble to "prune" unnecessary cards and correspondence and to staple everything in date order, I think they would find them reasonably satisfactory.-I am, etc.,

Leeds

J. M. BRowN

SIR,- - I have received and read with dismay the ECN 946 on the subject of the redesign of medical records in general practice. It would appear that wise persons have decided to adopt (and have no doubt already printed) a new A4 size of record folder.

The circular states that "floor space needed per 1,000 records . . . will be at least twice that needed for the present ECs 5 and 6." Leaving aside the question of whether or not the EC 5, which has lasted for 50 years, is not an excellent and adequate vehicle for general practice medical records, I think that most doctors in the country have probably not had cause or time to consider the very great alteration which will be necessary to accommodate the new medical record folders.

The dimensions of the present medical record card are 5 in $\times 7$ in and have therefore an area of $35 \mathrm{in}^{2}$. The proposed new folder measures $12 \frac{1}{4}$ in $\times 9 \frac{1}{2}$ in, with an area of more than $110 \mathrm{in}^{2}$. Bearing in mind that the folder will be probably twice as thick as a present medical record folder, simple arithmetic shows that the volume, never mind the area, of a new medical record will be six to eight times the volume of the old one. I am sure that my situation is no unique, in that it is impossible to put seven times the volume of filing cabinets that we

TABLE III-Relative Risks of Irradiation

\begin{tabular}{|c|c|c|c|c|c|c|c|c|c|c|c|c|c|c|c|c|c|c|c|c|c|c|}
\hline \multirow{2}{*}{\multicolumn{3}{|c|}{$\begin{array}{c}\text { Ages } \\
\text { (Years) }\end{array}$}} & \multicolumn{5}{|c|}{ Viral Infections } & \multicolumn{5}{|c|}{ Bacterial Infections } & \multicolumn{5}{|c|}{ Allergies } & \multicolumn{5}{|c|}{ Infections or Allergies } \\
\hline & & & $R_{1}$ & $\mathbf{R}_{2}$ & $R_{1} / R_{2}$ & E.P.* & $x_{1}^{2+}$ & $\mathbf{R}_{\mathbf{1}}$ & $\mathrm{R}_{2}$ & $R_{1} / R_{2}$ & E.P. & $x_{1}^{2}$ & $\mathbf{R}_{1}$ & $\mathbf{R}_{2}$ & $R_{1} / R_{2}$ & E.P. & $\chi_{1}^{2}$ & $\mathbf{R}_{1}$ & $\mathbf{R}_{2}$ & $\mathbf{R}_{\mathbf{1}} / \mathbf{R}_{\mathbf{2}}$ & E.P. & $x_{1}^{2}$ \\
\hline $\begin{array}{c}1-4 \\
5-9 \\
10-14\end{array}$. & $\begin{array}{l}. \\
\cdots\end{array}$ & $\begin{array}{l}. \\
\ldots\end{array}$ & $\begin{array}{l}1.68 \\
1.07 \\
0.68\end{array}$ & $\begin{array}{l}1.52 \\
1.24 \\
0.79\end{array}$ & $\begin{array}{l}1 \cdot 11 \\
0.86 \\
0.86\end{array}$ & $\begin{array}{l}0.53 \\
0.72 \\
0.80\end{array}$ & 0.00 & $\begin{array}{l}3 \cdot 50 \\
0 \cdot 75 \\
2 \cdot 70\end{array}$ & $\begin{array}{l}1.52 \\
1 \cdot 24 \\
0.79\end{array}$ & $\begin{array}{l}2 \cdot 30 \\
0 \cdot 60 \\
3 \cdot 42\end{array}$ & $\begin{array}{l}0 \cdot 25 \\
0 \cdot 85 \\
0 \cdot 41\end{array}$ & $0 \cdot 67$ & $\begin{array}{c}\infty \\
1.25 \\
4.50\end{array}$ & $\begin{array}{l}1.52 \\
1.24 \\
0.79\end{array}$ & $\begin{array}{c}\infty \\
1 \cdot 01 \\
5 \cdot 70\end{array}$ & $\begin{array}{l}0.34 \\
0.72 \\
0 \cdot 35\end{array}$ & $1 \cdot 25$ & $\begin{array}{l}2.24 \\
1.07 \\
1.66\end{array}$ & $\begin{array}{l}1.52 \\
1.24 \\
0.79\end{array}$ & $\begin{array}{l}1.47 \\
0 \cdot 86 \\
2 \cdot 10\end{array}$ & $\begin{array}{l}0.27 \\
0.73 \\
0 \cdot 48\end{array}$ & 0.59 \\
\hline
\end{tabular}

*E.P. = exact probability (one-sided).

In each age group the expected number of irradiated leukaemia cases with infections or allergy was calculated on the hypothesis that $\mathbf{R}_{\mathbf{1}}=\mathbf{R}_{\mathbf{2}}$. The variance was also calculated and $\chi^{2}$ computed as ( (Observed-Expected) $)^{2 / \Sigma}$ variance where the summation is over the three age groupings. 